\title{
Urgent Proceedings before the International Courts and Tribunals
}

\author{
Tafsir Malick Ndiaye \\ The International Tribunal for the Law of the Sea, Am Int. Seegerichtshof 1, Hamburg, Germany \\ Email: ndiaye@itlos.org
}

How to cite this paper: Ndiaye, T. M. (2019). Urgent Proceedings before the International Courts and Tribunals. Beijing Law Review, 10, 839-868.

https://doi.org/10.4236/blr.2019.104046

Received: July 22, 2019

Accepted: August 29, 2019

Published: September 2, 2019

Copyright (c) 2019 by author(s) and Scientific Research Publishing Inc. This work is licensed under the Creative Commons Attribution International License (CC BY 4.0).

http://creativecommons.org/licenses/by/4.0/

\begin{abstract}
The urgent proceedings of the International Tribunal for the Law of the Sea reflect the Tribunal multi-faceted jurisdiction contained in the Rules. These proceedings are expeditious and cost-effective. They last about two months instead of thirty months as in the procedure on the merits. These proceedings help States to face emergency issues at hand. It appeared determinant after the two cases, i.e. case $\mathrm{N}^{\circ} 26$ concerning the Detention of three Ukrainian naval vessels in its order of 25 May 2019 and case $N^{\circ} 27$, The M/T "San Padre Pio" in its order of 6 July 2019, to make plane and clarify the legal regime of urgent proceedings specially with new challenges for the international community as a whole, such as the climate change, the Sea level rise and the Biodiversity Beyond National Jurisdiction (BBNJ).
\end{abstract}

\section{Keywords}

Proceedings, Incidental Proceedings, Provisional Measures, Preliminary

Proceedings, Preliminary Objections, Counter Claim, Intervention,

Discontinuance, Prompt Release Proceedings

\section{Introduction}

For permanent international courts such as the International Tribunal for the Law of the Sea (ITLOS), the law applicable to procedure follows the same principle as that governing the merits of a case. Although, to a great extent, the law is already set down, the Tribunal plays an important role in its establishment. The basis on which contentious proceedings are conducted before the Tribunal is essentially the Statute and Rules of the Tribunal (NDIAYE, 2009).

The Rules of the International Tribunal for the Law of the Sea were adopted on 28 October 1997 after months of deliberations from October 1996. ITLOS had to take into account the UNCLOS provisions, especially Annex VI thereto, 
which is the Tribunal's Statute that empowers the body to adopt Rules of procedure, i.e., in broad lines, the organisation of the Tribunal and the procedure to be followed in cases submitted to it.

The Statute of the Tribunal develops a certain number of principles set out in Section 2 of Part XV of the United Nations Convention on the Law of the Sea (hereinafter the Convention). It is an integral part of the Convention and forms Annex VI thereto. It can be amended only by the same procedure as amendment of the Convention ${ }^{1}$ and, since the Convention and the Statute are in existence, potential litigant parties have no further role to play in the establishment of rules governing their case.

However, these rules are still too general to cover every question that might arise as a case proceeds, and it is for that reason that judges require rules of application. Thus the Statute ${ }^{2}$ of the Tribunal recognises the latte's power to establish a set of rules of procedure, the object of which is right to supplement the general rules laid down in the Convention and the Statute and to specify in detail the measures to be taken in order to give effect to the rules imposed thereon. Therefore, the Rules may not contain provisions that are contrary to or contravene those set out in the Statute. The Tribunal cannot grant itself prerogatives not conferred by the Statute. In other words, owing to the different status of their authors, the Statute and the Rules do not have the same juridical value.

Indeed, although the Tribunal is bound by the Statute, which forms an integral part of the Convention, it may amend or modify the Rules, which the Tribunal itself established ${ }^{3}$. However, despite the difference between these two texts, the common objective of their authors is to ensure that parties to proceedings

\footnotetext{
${ }^{1}$ Article 41 of the Statute provides: "l. Amendments to this Annex, other than amendments to section 4, may be adopted only in accordance with Article 313 (of the Convention) or by consensus at a conference convened in accordance with this Convention. - 2. Amendments to section 4 may be adopted only in accordance with Article 314. - 3. The Tribunal may propose such amendments to this Statute as it may consider necessary, by written communications to the States Parties for their consideration in conformity with paragraphs I and 2."

${ }^{2}$ Article 16 of the Statute provides: "The Tribunal shall frame rules for carrying out its functions. In particular, it shall lay down rules of procedure." Thus, the international Tribunal for the Law of the Sea drew up Rules and adopted them on 28 October 1997.

${ }^{3}$ On many occasions, the International Court of Justice has had to recall the intangible nature of the Statute. Indeed, following Albania's failure to attend in the third stage of the Corfu Channel Case in which the Court was to determine the amount of the compensation to be paid to the United Kingdom, Albania maintaining that the special agreement of 25 March 1948 did not confer jurisdiction on the Court to fix the amount of the compensation, the Court had to throw out the argument, recalling its judgment of 25 March 1948, by means of which competence was conferred on the Court, and stating "in accordance with the Statute (Article 60), which, for the settlement of the present dispute, is binding upon the Albanian Government"; see I.C.J. Reports 1949, p. 248. The Court also stated, in the Haya de la Torre Case, that it should not depart from the principle set out in Article 43, paragraph 1, of its Statute, whereby the procedure was divided into a written and an oral phase, in response to the parties which had suggested that the oral phase of the proceedings be dispensed with. It should be noted that, if this case had been dealt with by the International Tribunal for the Law of the Sea, the latter would have been able to follow the suggestion made by Colombia and Peru insofar as it is the Rules of the Tribunal (Article 44, paragraph 1) which set down the principle of two procedural phases. On the other hand, the court or tribunal may take whichever decisions it sees fit for the conduct of proceedings, provided they are compatible with the provisions of the Statute.
} 
are treated equally.

The aim thereof is to enable the proceedings to reach their conclusion as a result of rules being properly applied and parties systematically presenting their claims and counter-claims so that the legal truth can be established.

The proceedings are supposed to be conducted without unnecessary delay or expense. This affects the time-limits and other devices to meet the need for making the procedure expeditious. Transparency is also a basic principle followed by the Rules, as regard to the appearance before the Tribunal and the access for the public to the written pleadings of a case.

To that end, the Tribunal applies the provisions of the Statute and of the Rules. Alongside these two texts, which set down in detail the modalities according to which a case should be conducted, procedure is governed by the Convention, the Resolution on the Internal Judicial Practice of the Tribunal, and by the Guidelines concerning the Preparation and Presentation of Cases before the Tribunal ${ }^{4}$.

It is by applying this principle of equality between parties that the President of the Tribunal should, pursuant to Article 45 of the Rules, ascertain the views of the parties with regard to questions of procedure. It is this same principle which should predicate all decisions taken or to be taken with respect to the order in which pleadings should be submitted-the burden of proof, the hearing of the parties and their right to respond, the allotment of time for preparing files, and the time accorded to speakers. It is worth noting that generally when a case is brought by means of compulsory jurisdiction through a unilateral application, the competence of said jurisdiction and the admissibility of the request are often challenged. The subject of application or claims that may lead to non-appearance are often highly political matters, relating to sovereignty, independence, or simply national prestige, which explains the defiant attitude of governments towards International Courts and Tribunals (NDIAYE, 2013) (Alexandrov, 1995) (Bowett, 1983) (FITZMAURICE, 1980). As concerns the sanctioning of rules of procedure, the nature of the sources has an effect on the form which that sanction takes. No well-established practice appears to exist. Although there is a tendency for the failure to recognise procedural rules having their origin in an agreement between the parties being sanctioned with inadmissibility, on the other hand, the applicability of this same sanction when the author of the rule of procedure is the Tribunal is shrouded in uncertainty. It must be stated that the litigant parties are sovereign States, which consent to appear before International Courts. In the Juno Trader Case before the Tribunal, it will be recalled that Guinea-Bissau did not produce its statement in response, contrary to the request of Saint Vincent and the Grenadines. However, it did indeed attend the entire oral proceedings.

Should the provisions of the Rules ${ }^{5}$ be amended in order to deal with such a

${ }^{4}$ These texts can be accessed via the Tribunal's website. See also the Guide to Proceedings before the Tribunal at http://www.itlos.org/.

${ }^{5}$ See Article 111, paragraph 4 of the Rules; see also -Juno Trader case (St Vincent and the Grenadines V. Guinea-Bissau) prompt release, judgment of 18 December 2004. 
case of failure to observe due process?

Finally, in order to expedite cases, the Tribunal annually creates a chamber which is composed of five of its elected members and is called upon to hear and determine disputes by summary procedure. Two alternative members are also selected ${ }^{6}$.

Any judgment rendered by one of these Chambers is considered to have been rendered by the Tribunal. Procedure before the Chambers is regulated in accordance with the provisions concerning proceedings before the Tribunal, subject to any particular provisions, which the latter may adopt.

We will study the incidental proceedings (I) before examining the prompt release proceedings (II).

\section{Incidental Proceedings ${ }^{7}$}

These proceedings do not initiate a new proceeding but do affect its ordinary course. They can be a means found to have the proceedings declared inadmissible and to have its course suspended or terminated.

Incidental proceedings could be considered either as incidents relating to the modification of elements of the legal links of the proceedings, or as incidents of proceedings. They lead to an interlocutory judgment that will allow the Tribunal to render an order, which, although having an immediate effect, shall not be definitive. It could also result in a definitive judgment benefiting both parties, whether the Tribunal has no jurisdiction or whether it adjudicates on the merits. We will examine the provisional measures (I.1), the preliminary proceedings (I.2), the preliminary objections (I.3), the counter-claims (I.4), the intervention (I.5) and the discontinuance (I.6).

\subsection{Provisional Measures}

Provisional measures, which parties to a dispute may request the Tribunal are «prescribed» and not «indicated» and the parties shall comply with any provisional measures prescribed. Thus, the measures are meant to be binding. The

\footnotetext{
${ }^{6}$ Article 15, paragraph 3 of the Statutes.

${ }^{7}$ As stated by the International Court of Justice: "Incidental proceedings by definition must be those, which are incidental to a case, which is already before the Court or Chamber. An incidentai proceeding cannot be one, which transforms that case into a different case with different parties". Case concerning the land, island and maritime frontier dispute, (El Salvador v. Honduras), Judgment of 13 September 1990, Request for Intervention by Nicaragua, ICJ Reports 1990, p 134, paragraph 98. Speaking of the intervention, the Court (97) explains that the purpose of an intervention based on Article 62 of the Statute is to protect an "interest of a legal nature, of a State likely to be affected by a decision, in a pending case between other States, namely the parties to this case. Its purpose is not to put the intervening State in a position to graft a new case on the preceding, to become a new party and have the Court pronounces on its pretensions. An affair with a new party and new applications to be decided would be a new affair. The difference between the intervention, under section 62 , and the constitution of a new party to a case is not only a difference of degree; it's a difference of nature. As the Court pointed out in 1984;" Nothing in Article 62 indicates that this text was as another mean to bring an additional dispute before the Court-a matter falling under Article 40 of the Statute-or as a mean to assert the rights of a State not party to the case (Continental Shelf (Libyan Arab Jamahiriya v. Malt) Request to intervene, ICJ Reports 1984, page 23, paragraph 37).
} 
binding nature of the measures is echoed in the Tribunal Rules. Article 95 provides:

"Each party shall inform the Tribunal as soon as possible as to its compliance with any provisional measures the Tribunal has prescribed. In particular, each party shall submit an initial report upon the steps it has taken or proposes to take in order to ensure prompt compliance with the measures prescribed.

The Tribunal may request further information from the parties on any matter connected with the implementation of any provisional measures it has prescribed."

The Court or Tribunal may prescribe any provisional measures in any of these two cases:

"When a dispute has been duly submitted to a court or tribunal under Article 290 paragraph 1 of the Convention; and pending the constitution of an arbitral tribunal under Article 290, paragraph 5 of the Convention".

\subsubsection{Prior Referral to the Tribunal}

If a dispute has been duly submitted to a court or tribunal which considers that prima facie it has jurisdiction under this Part or Part XI, Section 5, the court or tribunal may prescribe any provisional measures which it considers appropriate under the circumstances to preserve the respective rights of the parties to the dispute or to prevent serious harm to the marine environment, pending the final decision ${ }^{8}$.

A party may submit a request for the prescription of provisional measures any time during the course of the proceedings in a dispute submitted to the Tribunal'. The request must be in writing and must specify the measures requested, the reasons therefore, and the possible consequences, if it is not granted, for the preservation of the respective rights of the parties or for the prevention of serious harm to the marine environment ${ }^{10}$.

The Tribunal may also prescribe provisional measures to prevent damage to fish stocks in accordance with article 31, paragraph 2, of the Agreement for the Implementation of the Provisions of the United Nations Convention on the Law of the Sea of 10 December 1982 relating to the Conservation and Management of Straddling Fish Stocks and Highly Migratory Fish Stocks (United Nations Convention on the Law of the Sea, 1982).

In the Saiga case, Saint Vincent and the Grenadines submitted a request for the prescription of provisional measures. Following the exchange of letters of 20 February 1998, constituting an agreement between Guinea and Saint Vincent and the Grenadines to institute proceedings before the Tribunal concerning the Saiga vessel, the Tribunal had to give an order, which will consider the request for prescription of provisionary measures as duly presented before the Tribunal, in accordance with article 290, paragraph 1 of the Convention (The Saïga case,

${ }^{8}$ Article 290, paragraph 1 of the Convention.

${ }^{9}$ Article 89, paragraph 1 of the Rules.

${ }^{10}$ Article 89, paragraph 3 of the Rules. 
St. Vincent and the Grenadines vs. Guinea, 1998). It must be noted that after the introduction of an application by Saint Vincent and the Grenadines for a prompt release of the Saiga and its crew, in accordance with article 292 of the Convention, the Tribunal gave its judgment on 4 December 1997. The pending procedure between the two states was related to the merits of the dispute, at that time (Saint Vincent and the Grenadines Vs Guinea, 1999).

Provisional measures may also be prescribed when a dispute on the merits is submitted pending the constitution of an arbitral tribunal.

\subsubsection{Pending the Constitution of an Arbitral Tribunal \\ Prescription of measures}

Pending the constitution of an arbitral tribunal to which a dispute is being submitted under this section, any court or tribunal agreed upon by the parties or, failing such agreement within two weeks from the date of the request for provisional measures, the International Tribunal for the Law of the Sea or, with respect to activities in the Area, the Seabed Disputes Chamber, may prescribe, modify or revoke provisional measures in accordance with this article if it considers that prima facie the tribunal which is to be constituted would have jurisdiction and that the urgency of the situation so requires. Once constituted, the tribunal to which the dispute has been submitted may modify, revoke or confirm those provisional measures, acting in conformity with paragraphs 1 to $4^{11}$.

Provisional measures may be prescribed, only at the request of a party to the dispute and after the parties have been given an opportunity to be heard ${ }^{12}$.

A request may be submitted at any time after two weeks from the notification to the other party of a request for provisional measures if the parties have not agreed that such measures may be prescribed by another court or tribunal ${ }^{13}$.

If the Tribunal is not in session or a sufficient number of members is not available to constitute a quorum, the provisional measures shall be prescribed by the chamber of summary procedure formed under article 15, paragraph 3, of the Statute. Notwithstanding article 15, paragraph 4, of the Statute, such provisional measures may be adopted at the request of any party to the dispute. They shall be subject to review and revision by the Tribunal. The Tribunal shall review or revise provisional measures at the written request of a party within 15 days of the prescription of the measures. The Tribunal may also at any time decide proprio motu to review or revise the measures ${ }^{14}$. This is an exception to the rule that the judicial body can only adjudicate within the limits of the Parties' request.

Provisional measures may be prescribed even if the Court or Tribunal is denied jurisdiction. This occurred in the "Southern Bluefin Tuna» ${ }^{15}$ case. New Zealand and Australia requested the Tribunal to prescribe provisional measures

${ }^{11}$ Article 290, paragraph 5 of the Convention.

${ }^{12}$ Article 290, paragraph 3 of the Convention.

${ }^{13}$ Article 89, paragraph 2 of the Rules.

${ }^{14}$ Article 25, paragraph 2 of the Statute. Article 15, paragraph 5 of the statute provides: “A judgment given by any of the chambers provided for in this article and in article 14 of this Annex shall be considered as rendered by the Tribunal".

${ }^{15}$ Article 91, paragraph 2 of the Rules. 
while Japan contested the jurisdiction of the judicial body. According to Japan:

Australia and New Zealand must satisfy two conditions before a tribunal constituted pursuant to Annex VII would have jurisdiction over this dispute such that this Tribunal may entertain a request for provisional measures pursuant to Article 290 (5) of UNCLOS pending constitution of such an Annex VII tribunal.

First, the Annex VII tribunal must have prima facie jurisdiction. This means among other things that the dispute must concern the interpretation or application of UNCLOS and not some other international agreement. Second, Australia and New Zealand must have attempted in good faith to reach a settlement in accordance with the provisions of UNCLOS Part X Section 1. Since Australia and New Zealand have satisfied neither condition, an Annex VII tribunal would not have prima facie jurisdiction and accordingly this Tribunal is without authority to prescribe any provisional measures (The Southern Bluefin Tuna case, 1999).

Considering that Australia and New Zealand have invoked as the basis of jurisdiction of the arbitral tribunal article 288, paragraph 1, of the Convention which reads as follows: " $A$ court or tribunal referred to in article 287 shall have jurisdiction over any dispute concerning the interpretation or application of this Convention, which is submitted, to it in accordance with this Part"16.

In the view of the Tribunal, the provisions of the Convention on the Law of the Sea invoked by Australia and New Zealand appear to afford a basis on which the jurisdiction of the arbitral tribunal might be founded ${ }^{17}$;

Considering that the conservation of the living resources of the sea is an element in the protection and preservation of the marine environment; Considering that there is no disagreement between the parties that the stock of Southern Bluefin Tuna is severely depleted and is at its historically lowest levels and that this is a cause for serious biological concern ${ }^{18}$; based on these grounds, the Tribunal found the provisional measures appropriate, in this regard.

Provisional measures have also been prescribed in the Land reclamation case ${ }^{19}$ by the Tribunal, even if its jurisdiction and the admissibility of the application have been disputed.

In this case, "Singapore believes that, on the merits, Malaysia's request for provisional measures should be dismissed, but I hope to show that ITLOS should not reach that question but should, instead, reject at the very threshold of the dispute Malaysia's request for provisional measures on the grounds of lack of jurisdiction and inadmissibility as well as because of exploitation and violation by Malaysia of fundamental prescribed procedures (Land Reclamation, 2003). Singapore contends that Malaysia's Request (for the prescription of provisional measures) is inadmissible because it does not specify ... the possible consequences ... for the preservation of the respective rights of the parties or for the ${ }^{16}$ Ibid. pp. 289-290.

${ }^{17}$ Ibid. p 293, paragraph 40; see also paragraphs 41-44.

${ }^{18}$ Ibid. p 294, paragraph 52.

${ }^{19}$ Ibid. p 295, paragraph 40; see also paragraphs 70-71. 
prevention of serious harm to the marine environment', as required by Article 89 (3) of the ITLOS Rules; and further that the Request does not identify the urgency of the situation' as required by Article 89 (4) of the ITLOS Rules"20;

The Tribunal concluded, considering that, given the possible implications of land reclamation on the marine environment, prudence and caution require that Malaysia and Singapore establish mechanisms for exchanging information and assessing the risks or effects of land reclamation works and devising ways to deal with them in the areas concerned ${ }^{21}$.

\subsubsection{The Application}

Pending the constitution of an arbitral tribunal, the submission of a request for the prescription of provisional measures must be made in two phases. First, an arbitral proceeding is initiated by a written notification addressed to the other party. The notification must be accompanied by a statement of claim and the grounds upon which it is based. Second, the request must be notified to the other party. It can be jointly presented with the notice of arbitration.

The application may be submitted to the Tribunal after two weeks from the notification of the request $\mathrm{t}^{22}$.

The request shall be in writing and specify the measures requested, the reasons therefor and the possible consequences, if it is not granted, for the preservation of the respective rights of the parties or for the prevention of serious harm to the marine environment. It shall also indicate the legal grounds upon which the arbitral tribunal which is to be constituted would have jurisdiction and the urgency of the situation ${ }^{23}$. A certified copy of the notification or of any other document instituting the proceedings before the arbitral tribunal shall be annexed to the request ${ }^{24}$.

Upon receiving the request, the Registrar shall transmit a certified copy to the respondent all steps on behalf of the parties after proceedings have been instituted shall be taken by agents. Agents shall have an address for service at the seat of the Tribunal or in the capital of the country where the seat is located, to which all communications concerning the case are to be sent ${ }^{25}$. The respondent, upon receipt of the certified copy of the application, or as soon as possible thereafter, shall inform the Tribunal of the name of its agent ${ }^{26}$. The President is informed of proceeding questions before giving the appropriate orders.

The Tribunal, or the President if the Tribunal is not sitting, shall fix the earliest possible date for a hearing. The Tribunal shall take into account any observations that may be presented to it by a party before the closure of the hearing ${ }^{27}$. In

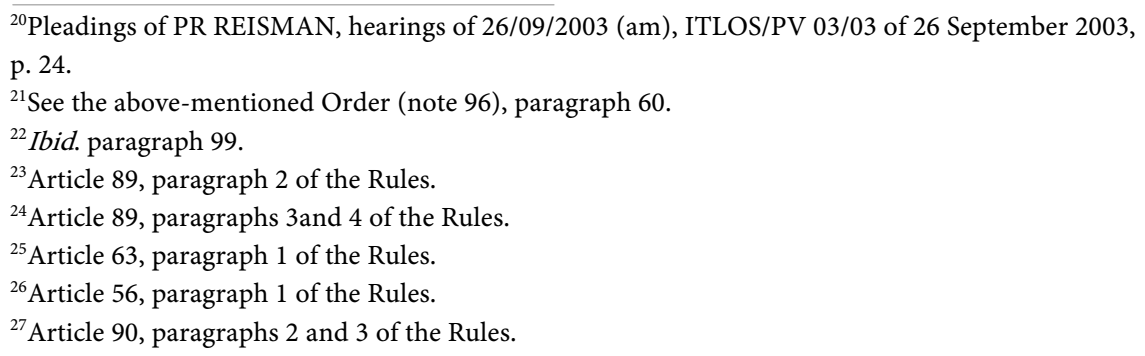


general, the respondents present their conclusions to the Tribunal before the opening of hearing.

The oral proceedings shall consist of the hearing by the Tribunal of agents, counsel, advocates, witnesses and experts ${ }^{28}$. The hearing shall be public, unless the Tribunal decides otherwise or unless the parties demand that the public be not admitted ${ }^{29}$. A request for the prescription of provisional measures has priority over all other proceedings before the Tribunal ${ }^{30}$. For these urgent proceedings, the hearings shall commence 2 or 3 weeks after submission of the request to the Tribunal. These will generally last 2 or 3 days by case. Each party can have its experts and witnesses heard.

They shall communicate to the Registrar a list of the surnames, first names, nationalities, descriptions and places of residence of the witnesses and experts whom the party intends to call, with indications of the point or points to which their evidence will be directed. A certified copy of the communication shall also be furnished for transmission to the other party ${ }^{31}$.

\subsubsection{The Order and Its Effects}

In the Tribunal's practice developed so far, there is approximately one month between the submission of the request for provisional measures and the rendering of the order. The order shall be read in a public hearing of the Tribunal. The court or tribunal shall forthwith give notice to the parties to the dispute, and to such other States Parties if it considers it appropriate ${ }^{32}$.

When a request for provisional measures has been made, the Tribunal may prescribe measures different in whole or in part from those requested and indicate the parties which are to take or to comply with each measure ${ }^{33}$. As indeed in the judgments, judges that do not vote with the majority of their colleagues may submit their dissident opinions or their individual opinions. They may also make declarations.

Each party to the dispute shall comply promptly with any provisional measures prescribed under article 290 of the Convention ${ }^{34}$. The compulsory nature conferred to the orders by the convention makes its application without delay compulsory for parties to the dispute. Article 290 of the Convention provides that the Tribunal-may prescribe ... provisional measures ...”.

The form of the prescription of provisional measures had cast doubts on the binding nature of these measures, due to the practice of the ICJ, which indicates these measures under article 41 of its Statute ${ }^{35}$, which has been the subject of controversy.

\footnotetext{
${ }^{28}$ Article 44, paragraph 3 of the Rules

${ }^{29}$ Article 26, paragraph 2 of the Statute.

${ }^{30}$ Article 90, paragraph 1 of the Rules; without prejudice to Article 112, paragraph 1 of the Rules regarding the application for prompt release of vessel and crew.

${ }^{31}$ Article 72 of the Rules.

${ }^{32}$ Article 290, paragraph 4 of the Convention.

${ }^{33}$ Article 89, paragraph 5 of the Rules.

${ }^{34}$ Article 290, paragraph 4 of the Convention.

${ }^{35}$ In its judgment on the merits of 27 June 2001 in the "LaGrand" case, the ICJ did not hesitate to assert the binding nature of its orders.
} 
It must be recalled that the decisions relating to the provisional measures are interlocutory judgments that allows the Tribunal to give an order, although having immediate effect that is not definitive. The binding nature stems, not only from the form but also its content. Moreover, the preparatory works to the convention clearly settle the question. The State-Parties, by choosing the expression-prescription of provisional measures intended to confer these legal decisions a binding character.

The Tribunal recalled in the Southern Bluefin Tuna case-the binding character of the prescribed measures and the provision set in article 290, paragraph 6 of the convention that one has to comply with these measures without delay ${ }^{36}$. That is why, each party must inform the Tribunal, as soon as possible, of the measures taken to implement the provisional measures prescribed by the Tribunal.

In particular, each party shall submit an initial report on the provisions taken or that it proposes to take to immediately comply with the prescribed measures $^{37}$. Furthermore, the Tribunal can ask for further information concerning questions relating to the implementation of the prescribed measures ${ }^{38}$.

Therefore, on one hand, as far as the provisional measures are concerned if a dispute has been duly submitted to a Court or a Tribunal which considers that prima facie it has jurisdiction, the Court or a Tribunal may prescribe any provisional measures which it considers appropriate under the circumstances to preserve respective rights of the parties or to prevent serious harm to the marine environment, pending the final decision.

On the other hand, pending the constitution of an Annex VII arbitral Tribunal, any court or Tribunal agreed upon by the parties or, failing such agreement within two weeks, ITLOS, or the Seabed dispute chamber may prescribe, modify, or revoke provisional measures if it considers that prima facie the Tribunal would have jurisdiction.

\section{Preliminary Proceedings}

This incidental proceeding is aimed at implementing Article 294 of the LOSC. This provision is linked to the compromise concerning the limitations to compulsory jurisdiction set out in Article 297 of the Convention.

A Court or Tribunal provided for in article 287 to which an application is made in respect of a dispute referred to in article 297 shall determine at the request of a party, or may determine whether the claim constitutes an abuse of legal process or whether prima facie it is well founded. If the court or tribunal determines that the claim constitutes an abuse of legal process or is prima facie unfounded, it shall take no further action in the case.

Upon receipt of the application, the court or tribunal shall immediately notify the other party or parties of the application, and shall fix a reasonable time-limit

\footnotetext{
${ }^{36}$ The Southern Bluefin Tuna case, op. cit. note 91, p. 297, paragraph 87.

${ }^{37}$ Article 95, paragraph 1 of the Rules.

${ }^{38}$ Article 95, paragraph 2 of the Rules.
} 
within which they may request it to make a determination.

The Tribunal may also decide, within two months from the date of an application, to exercise proprio motu its power under article 294, paragraph 1, of the Convention ${ }^{39}$.

The request by the respondent for a determination under article 294 of the Convention shall be in writing and shall indicate the grounds for a determination by the Tribunal that the application is made in respect of a dispute referred to in article 297 of the Convention; and the claim constitutes an abuse of legal process or is prima facie unfounded ${ }^{40}$.

Upon receipt of such a request or proprio motu, the Tribunal, or the President if the Tribunal is not sitting, shall fix a time-limit not exceeding 60 days within which the parties may present their written observations and submissions. The proceedings on the merits shall be suspended ${ }^{41}$. Unless the Tribunal decides otherwise, the further proceedings shall be oral ${ }^{42}$.

The written observations and submissions and the statements and evidence presented at the hearings shall be confined to those matters which are relevant to the determination of whether the claim constitutes an abuse of legal process or is prima facie unfounded, and of whether the application is made in respect of a dispute referred to in article 297 of the Convention. The Tribunal may, however, request the parties to argue all questions of law and fact, and to adduce all evidence, bearing on the issue ${ }^{43}$. The Tribunal shall make its determination in the form of a judgment ${ }^{44}$.

We shall stress the rare cases of preliminary procedures. However, the question had been raised in the CAMUCO case between Panama and France (The Camouco case, 2000) concerning the admissibility of the request.

France representative, M. Dobelle stated that:

"I should now like to look into questions concerning the admissibility of the application. First, the admissibility of the application, at least in part, might first be invoked on the grounds that it is similar to an abuse of legal process. I stress abuse of legal process and not an abuse of right as was alleged this morning. France is, of course, not aware that the preliminary proceedings laid down in article 294 of the Convention are not applicable in principle. Moreover, they would be difficult to apply in practice in the context of their case relating to a question of prompt release as covered by article 292.

However, the notion of the abuse of process to which the procedures laid down in article 294 are intended to serve as a response is not entirely alien to the present case.

In alleging that France has violated the provisions of article 58 of the Convention, the Panamanian application purely and simply alleged that the coastal state

\footnotetext{
${ }^{39}$ Article 96, paragraph 3 of the Rules.

${ }^{40}$ Article 96, paragraph 4 of the Rules.

${ }^{41}$ Article 96, paragraph 5 of the Rules.

${ }^{42}$ Article 96, paragraph 6 of the Rules.

${ }^{43}$ Article 96, paragraph 7 of the Rules.

${ }^{44}$ Article 96, paragraph 8 of the Rules.
} 
has acted in contravention of the provisions of the Convention with respect to the freedoms and rights of navigation as laid down in article $297^{45}$.

However, even though it has been shown that this allegation does not fall within the jurisdiction of the Tribunal in the proceedings forming the object of the present case, the fact nevertheless remains that Panama appears to be submitting an application in respect of a dispute referred to in article 297 according to the terms of article 294. This would entitle France to regard the application making such a request as an abuse of process. I shall limit myself to raising this question as it is up to the Tribunal to judge.

The Tribunal did not follow this argument, in this regard.

\subsection{The Preliminary Objections}

The Tribunal was inspired by the need for expeditious proceedings when it adopted the provisions concerning preliminary objections. To that end, the time-limits is shortened to 90 days.

Preliminary objections are a "mean invoked during the first phase of the proceedings, so that the Tribunal may rule on a preliminary question before going into the merits of the case" ${ }^{\prime 6}$.

The rules of the Tribunal characterise the preliminary objections by the effect of its invocation during the course of proceedings. When a mean has the effect to terminate proceedings on the merits, it is a preliminary objection of inadmissibility. When, in contrary, it has the effect to suspend the proceedings on the merits until some conditions are met, it is an admissibility objection of the request, as for instance, in the case of exhaustion of domestic remedies.

In each case, the Tribunal has to rule because "in any objection to the jurisdiction of the Tribunal, the Tribunal has to decide"47.

The procedure to follow is defined in article 97 of the Rules of the Tribunal. Any objection to the jurisdiction of the Tribunal or to the admissibility of the application, or other objection the decision upon which is requested before any further proceedings on the merits, shall be made in writing within 90 days from the institution of proceedings ${ }^{48}$.

The preliminary objection shall set out the facts and the law on which the objection is based, as well as the submissions ${ }^{49}$.

Upon receipt by the Registry of a preliminary objection, the proceedings on the merits shall be suspended and the Tribunal, or the President if the Tribunal is not sitting, shall fix a time-limit not exceeding 60 days within which the other party may present its written observations and submissions. It shall fix a further time-limit not exceeding 60 days from the receipt of such observations and submissions within which the objecting party may present its written observations and submissions in reply. Copies of documents in support shall be annexed to ${ }^{45}$ Ibid, Hearings of the 27 January 2000, (pm).

${ }^{46}$ J. BASDEVANT, Dictionnaire de la Terminologie du Droit International.

${ }^{47}$ Article 288, paragraph 4 of the Convention. See also Article 58 of the Rules.

${ }^{48}$ Article 97, paragraph 1 of the Rules.

${ }^{49}$ Article 97, paragraph 2 of the Rules. 
such statements and evidence, which it is proposed to produce, shall be mentioned ${ }^{50}$. Unless the Tribunal decides otherwise, the further proceedings shall be oral $^{51}$.

The written observations and submissions referred to in paragraph 3, and the statements and evidence presented at the hearings contemplated by paragraph 4 , shall be confined to those matters which are relevant to the objection. Whenever necessary, however, the Tribunal may request the parties to argue all questions of law and fact and to adduce all evidence bearing on the issue ${ }^{52}$. After that, starts the deliberation phase.

The Tribunal shall give its decision in the form of a judgment, by which it shall uphold the objection or reject it or declare that the objection does not possess, in the circumstances of the case, an exclusively preliminary character. If the Tribunal rejects the objection or declares that it does not possess an exclusively preliminary character, it shall fix time-limits for the further proceedings ${ }^{53}$.

Finally, The Tribunal shall give effect to any agreement between the parties that an objection submitted under paragraph 1 be heard and determined within the framework of the merits ${ }^{54}$.

The Joinder of preliminary objection to the merits has been applied by the Tribunal in the Saiga case $\left(\mathrm{N}^{\circ} 2\right)$ on the basis of the 20 February 1998 Agreement between Guinea and Saint Vincent. Article 2 provides:

"The written and oral proceedings before the International Tribunal for the Law of the Sea shall comprise a single phase dealing with all aspects of the merits (including damages and costs) and the objection as to jurisdiction raised in the Government of Guinea's, Statement of Response dated 30 January 1998"55.

Preliminary objections are often raised by the respondent when proceedings are instituted by mean of an application. This was indeed the case before this tribunal, particularly in matters it exercises a compulsory jurisdiction.

\subsection{Counter Claims}

A counter claim is an incidental claim through which a party to the proceedings seek to obtain, on top of the dismissal of the request initiated against it, the satisfaction by the adverse party of a claim having connection with the subject matter of the request of that party ${ }^{56}$.

Under article 98 of ITLOS Rules, three conditions have to be met, for a counter-claim to be admissible.

First, a party may present a counter-claim provided that it is directly connected with the subject-matter of the claim of the other party.

Then, the counter claim shall come within the jurisdiction of the Tribunal.

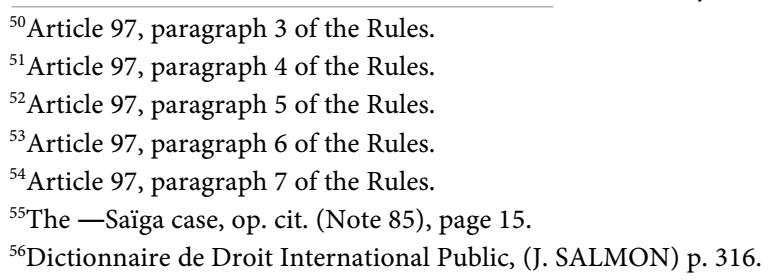


And finally, it shall be made in the counter-memorial of the party presenting it and shall appear as part of the submissions of that party ${ }^{57}$.

This latter condition shows that the proceedings must be introduced by a mean of an application, putting the parties in a defendant/respondent relationship.

It remains very difficult to formulate a counter-claim during the course of a procedure initiated by a special agreement, where there is neither defender, nor respondent and where the presentation of pleadings can be simultaneous ${ }^{58}$.

In the event of doubt as to the connection between the question presented by way of counter-claim and the subject-matter of the claim of the other party the Tribunal shall, after hearing the parties, decide whether or not the question thus presented shall be joined to the original proceedings ${ }^{59}$.

Given that a counter-claim is an incidental claim, the Tribunal may adjudicate in the same terms as the original one. Thus, the fate of the two types of claim appears to be connected.

In the Southern Bluefin Tuna case, japan presented a counter claim ${ }^{60}$ but the Tribunal did not decide on this plea.

\subsection{Intervention}

A modification of the constituent of the legal links of the procedure characterised by the respective claims of the Parties, determining the subject-matter of the dispute, established by the legal act initiating the proceedings and the conclusions, may occur.

The intrusion of a third party in the course of a proceeding is called an intervention $^{61}$. Two types of intervention are envisaged in the ITLOS Statute. The so-called optional intervention triggered by a request upon which it shall be for the Tribunal to decide and the intervention-as of right to which a State is entitled when the construction of a Convention to which it is a party, is in question. If a request to intervene is granted, the decision of the Tribunal in respect of the dispute shall be binding upon the intervening State-Party.

There must be a distinction between the request to intervene ${ }^{62}$ and the right to intervene regarding interpretation or application issues ${ }^{63}$.

In the first case, should a State Party consider that it has an interest of a legal nature, which may be affected by the decision in any dispute; it may submit a request to the Tribunal to be permitted to intervene. It shall be for the Tribunal to decide upon this request. If a request to intervene is granted, the decision of the Tribunal in respect of the dispute shall be binding upon the intervening State

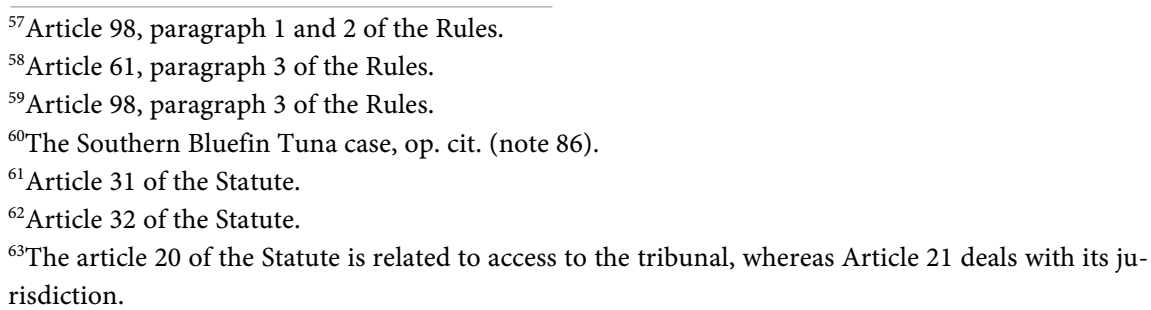


Party in so far as it relates to matters in respect of which that State Party intervened. The intervening party must show evidence it has interest to intervene.

In the second case, whenever the interpretation or application of this Convention is in question, the Registrar shall notify all States Parties forthwith.

Whenever pursuant to article 31 or 32 of LOSC Annex VI ${ }^{64}$ the interpretation or application of an international agreement is in question, the Registrar shall notify all the parties to the agreement.

Every party has the right to intervene in the proceedings; if it uses this right, the interpretation given by the judgment will be equally binding upon it.

The request to intervene and the right to intervene procedures are defined in the Rules of Tribunal.

An application for permission to intervene under the terms of article 31 of the Statute shall be filed not later than 30 days after the counter-memorial becomes available under article 67, paragraph 1 , of these Rules. In exceptional circumstances, an application submitted at a later stage may however be admitted.

The application shall be signed, and state the name and address of an agent. It shall specify the case to which it relates and shall set out: a) the interest of a legal nature which the State Party applying to intervene considers may be affected by the decision in that case; $b$ ) the precise object of the intervention.

Permission to intervene under the terms of article 31 of the Statute may be granted irrespective of the choice made by the applicant under article 287 of the Convention. The application shall contain a list of the documents in support, copies of which documents shall be annexed ${ }^{65}$.

A State Party or an entity other than a State Party referred to in article 32, of the Statute which desires to avail itself of the right of intervention shall file a declaration to that effect. The declaration shall be filed not later than 30 days after the counter-memorial becomes available under article 67, paragraph 1, of these Rules. In exceptional circumstances, a declaration submitted at a later stage may, however, be admitted.

The declaration shall be signed by the agent and state his name and address. It shall specify the case to which it relates and shall: a) identify the particular provisions of the Convention or of the international agreement the interpretation or application of which the declaring party considers to be in question; b) set out the interpretation or application of those provisions for which it contends; $c$ ) list the documents in support, copies of which documents shall be annexed ${ }^{66}$.

Certified copies of the application for permission to intervene under article 31 of the Statute, or of the declaration of intervention under article 32 of the Statute, shall be communicated forthwith to the parties to the case, which shall be invited to furnish their written observations within a time-limit to be fixed by the Tribunal or by the President if the Tribunal is not sitting.

The Registrar shall also transmit copies to States Parties; any other parties

\footnotetext{
${ }^{64}$ Article 99 of the Rules.

${ }^{65}$ Article 100 of the Rules.

${ }^{66}$ Article 101 of the Rules.
} 
which have to be notified under article 32, paragraph 2, of the Statute; the Secretary-General of the United Nations; the Secretary-General of the Authority when the proceedings are before the Seabed Disputes Chamber ${ }^{67}$.

The Tribunal shall decide whether an application for permission to intervene under article 31 of the Statute should be granted or whether an intervention under article 32 of the Statute is admissible as a matter of priority unless in view of the circumstances of the case the Tribunal determines otherwise.

If, within the time-limit fixed under article 101, an objection is filed to an application for permission to intervene, or to the admissibility of a declaration of intervention, the Tribunal shall hear the State Party or entity other than a State Party seeking to intervene and the parties before deciding ${ }^{68}$.

If an application for permission to intervene under article 31 of the Statute is granted, the intervening State Party shall be supplied with copies of the pleadings and documents annexed and shall be entitled to submit a written statement within a time-limit to be fixed by the Tribunal. A further time-limit shall be fixed within which the parties may, if they so desire, furnish their written observations on that statement prior to the oral proceedings. If the Tribunal is not sitting, these time-limits shall be fixed by the President.

The time-limits shall, so far as possible, coincide with those already fixed for the pleadings in the case. The intervening State Party shall be entitled, in the course of the oral proceedings, to submit its observations with respect to the subject-matter of the intervention.

The intervening State Party shall not be entitled to choose a judge ad hoc or to object to an agreement to discontinue the proceedings ${ }^{69}$.

Regarding the right to intervene, the procedure set by article 104 of the Rules of the tribunal is the same. It is to be noted that the Tribunal has not yet examined an intervention case.

\subsection{Discontinuance}

If at any time before the final judgment on the merits has been delivered the parties, either jointly or separately, notify the Tribunal in writing that they have agreed to discontinue the proceedings, the Tribunal shall make an order recording the discontinuance and directing the Registrar to remove the case from the List of cases or docket.

If the parties have agreed to discontinue the proceedings in consequence of having reached a settlement of the dispute and if they so desire, the Tribunal shall record this fact in the order for the removal of the case from the List, or indicate in, or annex to, the order the terms of the settlement.

If the Tribunal is not sitting, any order under this article may be made by the President ${ }^{70}$.

\footnotetext{
${ }^{67}$ Article 102 of the Rules.

${ }^{68}$ Article 105, paragraph 2 of the Rules.

${ }^{69}$ Article 105, paragraph 3 of the Rules.

${ }^{70}$ Article 105, paragraph 3 of the Rules.
} 
These provisions have been applied by the Tribunal in the CHAISIRI REEFER 2 case between Panama and Yemen. The Tribunal said:

"Whereas the Agent of Panama addressed to the Acting Registrar of the Tribunal a letter dated 12 July 2001 which reads as follows: I have the honour to inform you that:

- In accordance with article 105 para 2 of the Rules of the Tribunal:

- The parties have agreed to discontinue the proceedings

- In consequence of having reached a settlement of the dispute concerning the arrest of "CHAISIRI REEFER 2" as follows:

"Places on record the discontinuance, by agreement of the Parties, of the proceedings initiated on 3 July 2001 on behalf of Panama against Yemen; and Orders that the case be removed from the List of cases ${ }^{71}$ "

If, in the course of proceedings instituted by means of an application, the applicant informs the Tribunal in writing that it is not going on with the proceedings, and if, at the date on which this communication is received by the Registry, the respondent has not yet taken any step in the proceedings, the Tribunal shall make an order officially recording the discontinuance of the proceedings and directing the removal of the case from the List of cases. A copy of this order shall be sent by the Registrar to the respondent.

If, at the time when the notice of discontinuance is received, the respondent has already taken some step in the proceedings, the Tribunal shall fix a time-limit within which the respondent may state whether it opposes the discontinuance of the proceedings. If no objection is made to the discontinuance before the expiration of the time-limit, acquiescence will be presumed and the Tribunal shall make an order recording the discontinuance of the proceedings and directing the Registrar to remove the case from the List of cases. If objection is made, the proceedings shall continue ${ }^{72}$. If the Tribunal is not sitting, its powers under this article may be exercised by the President.

\section{Prompt Release of Vessels and Crews}

This is another urgent procedure-with the provisional measures-set out in Article 292 of the LOSC. Certain conditions must be satisfied for the Tribunal to have jurisdiction: The detaining State has not complied with provisions of the Convention for the prompt release upon the posting of a reasonable bond and once the bond or financial security have been posted, the authorities of the detaining State shall comply promptly with the decision of the Tribunal concerning the release of the vessel or its crew.

An application for the release of a vessel or its crew from detention may be made under the conditions set by the Convention. First, where the authorities of a State Party have detained a vessel flying the flag of another State Party.

Then, it is alleged that the detaining State has not complied with the provisions of this Convention for the prompt release of the vessel or its crew upon the

\footnotetext{
${ }^{71}$ The Chaisiri Reefer 2 (Panama vs. Yemen), Order of 13 July 2001, ITLOS, Recueil, 2001, p. 82.
}

${ }^{72}$ Article 106 of the Rules. 
posting of a reasonable bond or other financial security, Finally, when the parties fail to reach an agreement within 10 days from the time of detention of the vessel or crew, to bring the issue of detention or arrest before an international Tribunal ${ }^{73}$.

In this special procedure, the Tribunal exercises a residual jurisdiction. It:

"Shall deal without delay with the application for release and shall deal only with the question of release, without prejudice to the merits of any case before the appropriate domestic forum against the vessel, its owner or its crew. The authorities of the detaining State remain competent to release the vessel or its crew at any time" 74

In this particular procedure, the Tribunal exercises a compulsory jurisdiction. We will examine the conditions of filing a request, the procedure and the judgment.

\subsection{Conditions for the Filing of a Request}

\section{a.Initiation of proceedings}

The procedure relating to the prompt release of the detention of a vessel or the liberation of its crew is introduced by a request addressed to the Registrar ${ }^{75}$.

The application for release may be made only by or on behalf ${ }^{76}$ of the flag State of the vessel. In this case, State Party may at any time notify the State authorities of the flag State ${ }^{77}$ competent to authorize persons, as well as by documents stating that the person submitting the application is the person named in the authorization. The application shall contain a succinct statement of the facts and legal grounds upon which the application is based and supporting documents shall be annexed to the application ${ }^{78}$.

Under article 111, paragraph 2 of the Rules, the statement of facts shall specify the time and place of detention of the vessel and the present location of the vessel and crew, if known.

It shall also contain relevant information concerning the vessel and crew including, where appropriate, the name, flag and the port or place of registration of the vessel and its tonnage, cargo capacity and data relevant to the determination of its value, the name and address of the vessel owner and operator and particulars regarding its crew.

It shall specify the amount, nature and terms of the bond or other financial

\footnotetext{
${ }^{73}$ Article 292, paragraph 1 of the Convention.

${ }^{74}$ Article 292, paragraph 3 of the Convention.

${ }^{75}$ Article 24, paragraph 1 of the Statute, Article 292, paragraph 1 of the Convention, Article 110, paragraph 1 of the Rules.

${ }^{76}$ Article 292, paragraph 2 of the Convention, Article 110, paragraph 1 of the Rules.

${ }^{77}$ Article 110, paragraph 2 of the Rules stipulates that: A State Party may at any time notify the Tribunal of: a) the State authorities competent to authorize persons to make applications on its behalf under article 292 of the Convention; b) the name and address of any person who is authorized to make an application on its behalf; $c$ ) the office designated to receive notice of an application for the release of a vessel or its crew and the most expeditious means for delivery of documents to that office; d) any clarification, modification or withdrawal of such notification.

${ }^{78}$ Article 111, paragraphs 1 and 3 of the Rules.
} 
security that may have been imposed by the detaining State and the extent to which such requirements have been complied with;

And finally, the statement of facts shall contain any further information the applicant considers relevant to the determination of the amount of a reasonable bond or other financial security and to any other issue in the proceedings.

A certified copy of the application shall forthwith be transmitted by the respondent and the President of the Tribunal shall consult the parties regarding procedure questions.

\subsubsection{Statement in Response}

A certified copy of the application shall forthwith be transmitted by the Registrar to the detaining State, which may submit a statement in response with supporting documents annexed, to be filed as soon as possible but not later than 96 hours before the hearing ${ }^{79}$. The Tribunal may, at any time, require further information to be provided in a supplementary statement. The further proceedings relating to the application shall be oral.

\subsubsection{Oral Proceedings}

The prompt release procedure is an urgent procedure as the one relating to the prescription of provisional measures. The Tribunal shall give priority to applications for release of vessels or crews over all other proceedings before the Tribunal.

However, if the Tribunal is seized of an application for release of a vessel or its crew and of a request for the prescription of provisional measures, it shall take the necessary measures to ensure that both the application and the request ${ }^{80}$ are dealt with without delay. The Tribunal, or the President if the Tribunal is not sitting, shall fix the earliest possible date, within a period of 15 days commencing with the first working day following the date on which the application is received, for a hearing at which each of the parties shall be accorded, unless otherwise decided, one day to present its evidence and arguments ${ }^{81}$.

\subsubsection{The Judgment}

The jurisdiction of the Tribunal in this procedure is restricted. It only examines issues of prompt release. Also, The Tribunal shall in its judgment determine in each case whether or not the allegation made by the applicant that the detaining State has not complied with a provision of the Convention for the prompt release of the vessel or the crew upon the posting of a reasonable bond or other financial security is well-founded ${ }^{82}$.

In other words, the admissibility of an application, under article 292 of the convention, is subjected to evidence that the detaining state did not comply with the provisions of the convention dealing with the prompt release of vessel and

\footnotetext{
${ }^{79}$ Article 111, paragraph 4 of the Rules.

${ }^{80}$ Article 112, paragraph 1 of the Rules.

${ }^{81}$ Article 112, paragraph 3 of the Rules.

${ }^{82}$ Article 113, paragraph 1 of the Rules.
} 
crew. The provisions of the Convention regarding the prompt release are set by article 73, paragraph 2 of the Convention relating to the implementation of the rules of the coastal State.

It reads:

"Upon posting of a bond or financial security, it shall proceed without delay to the release of the vessel or the crew".

Article 113, paragraph 2 of the Rules of the Tribunal provides that If the Tribunal decides that the allegation is well-founded, it shall determine the amount, nature and form of the bond or financial security to be posted for the release of the vessel or the crew.

The Tribunal shall determine whether the bond or other financial security shall be posted with the Registrar or with the detaining State, If the bond or other financial security has been posted with the Registrar, the detaining State shall be promptly notified there of ${ }^{83}$.

The decision of the Tribunal shall be in the form of a judgment. The judgment shall be adopted as soon as possible and shall be read at a public sitting of the Tribunal to be held not later than 14 days after the closure of the hearing. The parties shall be notified of the date of the sitting. There shall be no more than 4 weeks between the date on which the application is received and the judgment.

Upon the posting of the bond or other financial security determined by the court or tribunal, the authorities of the detaining State shall comply promptly with the decision of the court or tribunal concerning the release of the vessel or its $\mathrm{crew}^{84}$.

To this day the Tribunal has entertained nine prompt release of vessels and crew cases (The Saïga case, 1997) (The Camuco case, 2000) (the Monte Confurco case, 2000) (the Grand Prince case, 2001) (The Chasiri Reefer 2 case, 2001) (The Volga case, 2002) (The Juno Trader case, 2004) (The Hoshinmaru case, 2007) (The Tomimaru case, 2007).

\section{Case Law}

\subsection{Saïga Case}

The M/V SAIGA is an oil tanker flying the flag of Saint-Vincent-and-the Grenadines. Its character at the relevant time was Lemania Shipping Group Limited, registered in Geneva, Switzerland. At the time of the incident with respect to which the proceedings were instituted, the M/V SAIGA served as a bunkering vessel supplying fuel oil to fishing vessels and other vessels operating off the coast of Guinea. In the early morning of 27 October 1997, the M/V SAIGA having crossed the maritime boundary between Guinea and Guinea Bissau, entered the exclusive economic zone of Guinea approximately 32 nautical miles from the Guinean island of Alcatraz. The same day, it supplied gas oil to three fishing vessels, the Guiseppe Primo, the Kriti and the Eleni S. On 28 October 1997, the

${ }^{83}$ Article 113, paragraph 3 and Article 114 paragraph 1 of the Rules.

${ }^{84}$ Article 292, paragraph 4 of the Convention. 
M/V SAIGA was arrested by Guinean Customs Patrol Boats. In the course of action, at least two crew members were injured. On the same day the vessel was brought to Conakry, Guinea, where the vessel and its crew were detained. Subsequently, two injured crew members were allowed to leave and the cargo was discharged in Conakry upon the orders of local authorities. Saint-Vincent-and-the-Grenadines instituted the proceedings under article 292 of the Law of the Sea Convention. In the SAIGA case, Guinea places the responsibility for any damage resulting from the use of force on the Master and crew of the ship (The MV "SAIGA" Case, 1999).

Examining the use of force of Guinea during the arrest of the SAIGA, ITLOS must take into account the circumstances of the arrest in light of the applicable rules of international law. Although the Convention does not contain any specific provision regarding the use of force, the applicable international law in article 293 of the Convention requires that the use of force must be avoided as far as possible and, where force is inevitable, it must not go beyond what is reasonable and necessary in the circumstances. In the view of the Tribunal, considerations of humanity must apply in the law of the sea, as they do in other areas of international law. In the same vein, the UN Fish Stocks Agreement concludes Article $22(1)(f)^{85}$ by recalling the use of force principle during ship arrests at sea ${ }^{86}$.

\subsection{Camuco Case}

The CAMOUCO is a fishing vessel flying the flag of Panama. Its owner is "Merco-Pesca" (SA) a company registered in Panama. On 16 September 1999, the CAMOUCO left the port of Walvis Bay (Namibia) to engage in longline fishing in the Southern seas. Its master was a Spanish national. On 28 September, the CAMOUCO was boarded by the French surveillance frigate Floréal in the economic exclusive zone of the Crozet Islands (French Colony), 160 nautical miles from the northern boundary of the zone. The procés-verbal of violation stated that six tonnes of frozen tooth fish were found in the holds of the CAMOUCO and that the Master was in breach of law on account of: Unlawful fishing in the EEZ of the Crozet Islands, under the French jurisdiction; attempted flight to avoid verification by maritime authority; etc. In the CAMUCO CASE, the vessel being in detention was not disputed. However, the parties were in disagreement whether the Master of the vessel was also in detention. It is admitted that the Master was under "Court supervision", that his passport has also been taken away from him by the French authorities, and that, consequently, he is not in a position to leave Réunion; the so-called "Controle judiciaire" in the French system. The Tribunal considers that, in the circumstances of this case, it ${ }^{85}$ See article 22 of the UN Fish Stocks Agreement dealing with the basic procedures for boarding and inspection pursuant to article 21. It establishes the rights and duties of the Inspecting State, the Flag State and actions to be taken in conflicting circumstances concerning the master of a vessel as well as international regulations.

${ }^{86}$ Article 22 (f) the UN Fish Stocks Agreement states that inspecting States shall "avoid the use of force except when and to the degree necessary to ensure the safety of the inspectors and where the inspectors are obstructed in the execution of their duties. The degree of force used shall not exceed that reasonably required in the circumstances". 
is appropriate to order the release of the Master in accordance with article 292, paragraph 1, of the Convention ${ }^{87}$.

\subsection{Monte Confurco Case}

In the MONTE CONFURCO case as well, the parties did not agree as to whether the Master was under arrest, because placed under "court supervision" by the French authorities, and his passport was taken away from him, according to article 292 of the convention. In the view of the Tribunal, being under "court supervision" is simply another form of detention (the MONTE CONFURCO case, 2000) (CAMOUCO case, 2000).

The issue of the detention of the Master and its crew also arose in the JUNO TRADER case (ST Vincent and the Grenadines V. Guinea) and the HOSHINMARU case (Japan v. Russian Federation), respectively (the JUNO TRADER case, 2004) (the HOSHINMARU case, 2007).

\subsection{Juno Trader Case}

In the JUNO TRADER case (the JUNO TRADER case, 2004) the parties were in disagreement whether the crew was detained. According to the Applicant, while some passports have been returned, as of 7 December 2004 the passports of six crew members have not been returned. The Respondent contended that Guinea-Bissau did not detain any crew members of the JUNO TRADER and returned passports on request. In a letter dated 15 December 2004, received during the Tribunal's deliberations, the Respondent informed the Tribunal that "the Guinea-Bissau authorities (FISCAP) have already delivered the remaining passports and all members of the crew can freely leave Guinea-Bissau". The letter added that "the remaining passports have already been delivered without any formal conditions (such as posting of a bond) and are free to leave Guinea Bissau". On 16 December 2004, the Applicant, whilst confirming the information regarding delivery of passports, did not withdraw its request for an order from the Tribunal concerning the release of the members of the crew.

In this respect, the Tribunal notes that the members of the crew are still in Guinea-Bissau and subject to its jurisdiction. The Tribunal places on record the undertaking given by the Respondent in its letter dated 15 December 2004 and 26 declares that all members of the crew should be free to leave Guinea-Bissau without any conditions.

\subsection{Hoshinmaru Case}

In the HOSHINMARU case (the HOSHINMARU case, 2007). The Tribunal

${ }^{87}$ Article 292, paragraph 1, of the Convention states: "Where the authorities of a State Party have detained a vessel flying the flag of another State Party and it is alleged that the detaining State has not complied with the provisions of this Convention for the prompt release of the vessel or its crew upon the posting of a reasonable bond or other financial security, the question of release from detention may be submitted to any court or tribunal agreed upon by the parties or, failing such agreement within 10 days from the time of detention, to a court or tribunal accepted by the detaining State under article 287 or to the International Tribunal for the Law of the Sea, unless the parties otherwise agree”. 
notes the statement by the Respondent that the restrictions on the free movement of the Master were lifted on 16 July 2007. The Tribunal further notes that the Master and the crew still remain in the Russian Federation. For these reasons and in view of the circumstances of the case, the Tribunal finds that the Respondent has not complied with article 73 , paragraph 2, of the Convention, that the Application is well-founded, and that, consequently, the Russian Federation must release promptly the HOSHINMARU, including the catch on board and its crew in accordance with paragraph $102^{88}$.

The Tribunal decided that the Russian Federation must proceed into a prompt release of the HOSHINMARU, the master and the crew without further delay upon the posting of a reasonable bond or other security determined by the tribunal.

\subsection{Tominmaru Case}

In the TOMINMARU case (The Tomimaru case, 2007) (Japan vs. Russian Federation, 2007), it must be recalled the observations of the Tribunal relating to the confiscation and the international standards of due process.

As already declared by the tribunal in MONTE CONFURCO case judgment (the MONTE CONFURCO case, 2000), article 73 identifies two interests, the interest of the coastal State to take appropriate measures as may be necessary to ensure compliance with the laws and regulations adopted by it on the one hand and the interest of the flag State in securing prompt release of its vessels and their crews from detention on the other. It strikes a fair balance between the two interests. It provides for release of the vessel and its crew upon the posting of a bond or other security, thus protecting the interests of the flag State and of other persons affected by the detention of the vessel and its crew. The release from detention can be subject only to a "reasonable" bond. The Tribunal stress that a judgment under article 292 of the Convention must be without prejudice to the merits of any case before the appropriate domestic forum against the vessel, its owner or its crew. And this is to be taken into account to establish a fair balance between the interests of a coastal State and those of a flag State. It is the view of the Tribunal that confiscation of a fishing vessel must not be used in such a manner as to upset the balance of the interests of the flag State and of the coastal State as established in the Convention. A decision to confiscate eliminates the provisional character of the detention of the vessel rendering the procedure for its prompt release without object. Such a decision should not be taken in such a way as to prevent the ship owner from having recourse to available domestic judicial remedies, or as to prevent the flag State from resorting to the prompt release procedure set forth in the Convention; nor should it be taken through proceedings inconsistent with international standards of due process of law. A confiscation decided in unjustified haste would jeopardize the implementation of article 292 of the Convention. The Tribunal notes that the decision of the Su-

${ }^{88}$ Article 73, paragraph 2, of the Convention states that: "Arrested vessels and their crews shall be promptly released upon the posting of reasonable bond or other security.” 
preme Court of the Russian Federation brings to an end the procedures before the domestic courts. This has not been contested by the Applicant. After being informed of that decision, the Applicant did not maintain its argument that the confiscation of the TOMIMARU is not final. The Tribunal notes also that no inconsistency with international standards of due process of law has been argued and that no allegation has been raised that the proceedings which resulted in the confiscation were such as to frustrate the possibility of recourse to national or international remedies.

\subsection{Virginia G Case}

In the VIRGINIA G (the M/V "Virginia G" case, 2014) case Panama argues that it "is bringing this action against Guinea Bissau within the framework of diplomatic protection" and that it "takes the cause of its national and the vessel VIRGINIA G with everything on board, and every person and entity involved or interested in her operations".

To support its position, Panama refers to the SAIGA case (M/V "SAIGA", 1999) where the Tribunal states that "the Convention considers a ship as a unit, as regards the obligations of the flag State". Thus, the ship, everything on it, and every person involved or interested in its operations are treated as an entity linked to the flag State. The nationalities of these persons are not relevant. The judgment was rendered by the United Nations International Law Commission. We will remind that Panama refers also to article 18 of the draft articles on diplomatic protection adopted by the commission in 2006 regarding the protection of ships' crews, who have on board dozens of nationalities. It States: "The right of the State of nationality of the members of the crew of a ship to exercise diplomatic protection is not affected by the right of the State of nationality of a ship to seek redress on behalf of such crew members, irrespective of their nationality, when they have been injured in connection with an injury to the vessel resulting from an internationally wrongful act". On this basis, ITLOS concludes that the VIRGINIA G must be treated as an entity and that "each ship may have a crew of different nationalities". The similarities in prompt release system lie on the arrest of vessels. It is governed by the UNCLOS article 292 stating that were the authorities of a State-Party have detained a vessel flying the flag of another State-Party and it is alleged that the detaining State has not complied with the provisions of the Convention, the question may be submitted to the International Tribunal for the Law of the Sea. The differences reside in the nature of the vessels involved in the detention: Bunkering vessels, fishing vessels or any vessel performing an unlawful act in an EEZ.

\subsection{Case Concerning the Detention of Three Ukrainian Naval Vessels}

On 16 April 2019, Ukraine filed with the Tribunal a Request for the prescription of provisional measures (hereinafter "the Request") under article 290, paragraph 5, of the Convention in the dispute between Ukraine and the Russian Federation 
concerning the immunity of three Ukrainian naval vessels and the twenty-four servicemen on board. The case was entered in the List of Cases as Case No. 26 and named Case concerning the detention of three Ukrainian naval vessels.

In a note verbale dated 30 April 2019 and received in the Registry on the same date, the Embassy of the Russian Federation to the Federal Republic of Germany stated:

The Russian Federation is of the view that the arbitral tribunal to be constituted under Annex VII of UNCLOS will not have jurisdiction, including prima facie, to rule on Ukraine's claim, in light of the reservations made by both the Russian Federation and Ukraine under Article 298 of UNCLOS stating, inter alia, that they do not accept the compulsory procedures provided for in Section 2 of Part $X V$ thereof entailing binding decisions for the consideration of disputes concerning military activities. Furthermore, the Russian Federation expressly stated that the aforementioned procedures are not accepted with respect to disputes concerning military activities by government vessels and aircraft. For this obvious reason the Russian Federation is of the view that there is no basis for the International Tribunal for the Law of the Sea to rule on the issue of the provisional measures requested by Ukraine.

The Russian Federation has the honour to inform the International Tribunal for the Law of the Sea of its decision not to participate in the hearing on provisional measures in the case initiated by Ukraine, without prejudice to the question of its participation in the subsequent arbitration if, despite the obvious lack of jurisdiction of the Annex VII tribunal whose constitution Ukraine is requesting, the matter proceeds further.

However, in order to assist the International Tribunal for the Law of the Sea and in conformity with Article 90 (3) of the Rules, the Russian Federation intends to submit in due course more precise written observations regarding its position on the circumstances of the case.

The Tribunal notes that article 28 of the Statute reads:

When one of the parties does not appear before the Tribunal or fails to defend its case, the other party may request the Tribunal to continue the proceedings and make its decision. Absence of a party or failure of a party to defend its case shall not constitute a bar to the proceedings. Before making its decision, the Tribunal must satisfy itself not only that it has jurisdiction over the dispute, but also that the claim is well founded in fact and law ${ }^{89}$.

The Tribunal recalls that:

The absence of a party or failure of a party to defend its case does not constitute a bar to the proceedings and does not preclude the Tribunal from prescribing provisional measures, provided that the parties have been given an opportunity of presenting their observations on the subject (Arctic Sunrise, 2013) (Ndiaye, 2013) (Alexandrov, 1995) (Bowett, 1983) (FITZMAURICE, 1980).

\footnotetext{
${ }^{89}$ Article 28 of the statute.
} 
In this regard, the Tribunal recalls that "a State Party is not obliged to continue with an exchange of views when it concludes that the possibilities of reaching agreement have been exhausted" (MOX Plant, 2001) ("ARA Libertad", 2012) (Arctic Sunrise", 2013).

For these reasons, THE TRIBUNAL, prescribes, pending a decision by the Annex VII arbitral tribunal, that The Russian Federation shall immediately release the Ukrainian naval vessels Berdyansk, Nikopol and Yani Kapu, and return them to the custody of Ukraine and release the 24 detained Ukrainian servicemen and allow them to return to Ukraine.

\subsection{The M/T "San Padre Pio" Case}

On 21 May 2019, Switzerland submitted to the Tribunal a Request for the prescription of provisional measures (hereinafter "the Request") under article 290, paragraph 5, of the Convention in a dispute between Switzerland and Nigeria concerning the arrest and detention of the M/T "San Padre Pio", its crew and cargo. The case was entered in the List of Cases as Case No. 27 and named The M/T "San Padre Pio" Case.

In paragraph 45 of the Statement of Claim, Switzerland requests the arbitral tribunal to be constituted under Annex VII to the Convention (hereinafter "the Annex VII arbitral tribunal") to adjudge and declare that:

a) Nigeria has breached Switzerland's rights under UNCLOS as follows:

1) By intercepting, arresting and detaining the "San Padre Pio" without the consent of Switzerland, Nigeria has breached its obligations to Switzerland regarding the freedom of navigation as provided for in article 58 read in conjunction with article 87 of UNCLOS.

2) By intercepting the "San Padre Pio", by arresting the vessel and her crew and by detaining the vessel, her crew and cargo without the consent of Switzerland, Nigeria has breached its obligations to Switzerland regarding the exercise of exclusive flag State jurisdiction as provided for in article 58 read in conjunction with article 92 of UNCLOS.

3) By arresting the "San Padre Pio" and her crew, by detaining the vessel, her crew and cargo without the consent of Switzerland and by initiating judicial proceedings against them, Nigeria has breached its obligations to Switzerland in its own right, in the exercise of its right to seek redress on behalf of crew members and all persons involved in the operation of the vessel, irrespective of their nationality, in regard to their rights under the ICCPR [International Covenant on Civil and Political Rights] and the MLC [Maritime Labour Convention], and under customary international law.

b) The aforementioned breaches of UNCLOS constitute internationally wrongful acts entailing Nigeria's international responsibility.

c) These internationally wrongful acts entail legal consequences requiring $\mathrm{Ni}$ geria to:

1) cease, forthwith, the internationally wrongful acts continuing in time; 
2) provide Switzerland with appropriate assurances and guarantees that all the internationally wrongful acts referred to in subparagraph (a) above will not be repeated;

3) provide Switzerland full reparation for the injuries caused by all the internationally wrongful acts referred to in subparagraph (a) above.

The factual background underlying the Request which has been submitted to the Tribunal can be summarized as follows. On 23 January 2018, the Nigerian navy intercepted and arrested the M/T "San Padre Pio", a motor tanker flying the flag of Switzerland, while it was "engaged in one of several ship-to-ship ('STS') transfers of gasoil." The gasoil "was intended to supply the Odudu Terminal", an oil installation located within Nigeria's exclusive economic zone and operated by the company Total. According to Switzerland, at the time of the arrest, the vessel "was approximately 32 nautical miles from the closest point of Nigeria's coast" and within the exclusive economic zone of Nigeria. Switzerland adds that the ship-to-ship transfers took place "outside any safety zone that $\mathrm{Ni}$ geria could have established in accordance with UNCLOS... and well beyond the 200-metre area around installations to which Nigeria purports to extend its civil and criminal law."

According to Nigeria, the Nigerian naval vessel NNS "Sagbama" "encountered the San Padre Pio at the Odudu Oil Field at approximately 20:00 on the night of 22 January 2018, where it was bunkering a vessel." When the NNS "Sagbama" requested the M/T "San Padre Pio" to produce "regulatory approvals", it was presented with the bill of lading and a navy certificate, but "other required permits-the DPR Permit and the NIMASA (Nigeria Maritime Administration and Safety Agency) Certificate-were not shown." According to the report from the Nigerian navy, "the vessel had no proof of payment of the 3 per cent Import levy, sea protection and offshore oil reception facility levies at the point of arrest." Nigeria states that "subsequent investigation revealed that the NIMASA Certificate was obtained on 24 January 2018, that is, after the San Padre Pio had been arrested."

Switzerland and Nigeria are States Parties to the Convention, having ratified the Convention on 1 May 2009 and 14 August 1986, respectively. Upon ratification of the Convention, Switzerland made the following declaration pursuant to article 287, paragraph 1, of the Convention: "The Tribunal for the Law of the Sea has been designated as the only competent organ for disputes concerning law of the sea matters." Nigeria has not made a declaration pursuant to article 287, paragraph 1 , of the Convention.

In this respect, Nigeria notes that "the Annex VII arbitral tribunal may have jurisdiction over Switzerland's third claim only if, inter alia, the alleged dispute 'concerns the interpretation or application of the Convention"' and states that.

The alleged dispute regarding Switzerland's third claim does not concern the interpretation or application of UNCLOS but rather the interpretation and application of the ICCPR and the MLC. It thus falls outside of the jurisdiction of the Annex VII arbitral tribunal. 
Nigeria adds that "article 56(2) does not grant Annex VII arbitral tribunals the jurisdiction to determine violations of instruments outside of UNCLOS.

In light of the above circumstances, the Tribunal finds that there is a real and imminent risk of irreparable prejudice to the rights of Switzerland pending the constitution and functioning of the Annex VII arbitral tribunal. The Tribunal accordingly finds that the urgency of the situation requires the prescription of provisional measures under article 290, paragraph 5, of the Convention.

The Tribunal is of the view that, under article 290 of the Convention, it may prescribe a bond or other financial security as a provisional measure for the release of the vessel and the persons detained ${ }^{90}$.

The Tribunal notes in this regard that the release of a vessel upon the posting of bond is an option available under the "administrative procedure" in Nigeria, as stated by Counsel for Nigeria during the hearing in response to a question put by the Tribunal.

\section{Conclusion}

The use or abuse towards Annex VII arbitral proceedings of ITLOS must be contemplated. Apparently, the Tribunal has reverted to the invocation of the posting of a bond for the second time in its case law after the ARTIC SUNRISE

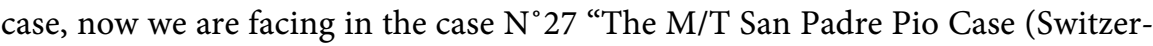
land v. Nigeria)", the same posture.

One must stress that prompt release proceedings and provisional measures proceedings are two different procedures governed respectively by UNCLOS articles 292 and 290. As Nigeria pointed out in case $\mathrm{N}^{\circ} 27$ :

"it may be worse noting in passing that this is not a prompt release case and thus, not a case where the State has an obligation under the Convention to release the vessel and allow the crew to depart ${ }^{1}$ ".

The prompt release proceedings have just been described and the Convention provides for the prompt release of vessel or crew upon the posting of a reasonable bond or other financial security.

It is mandatory procedure and in accordance with the Convention imprisonment or corporal punishment is prohibited as penalties for fishing offences (article 73, para. 3).

Therefore, the Tribunal must be cautious in dealing with the two different urgent proceedings.

\section{Conflicts of Interest}

The author declares no conflicts of interest regarding the publication of this paper.

${ }^{90} \mathrm{TM}$ NDIAYE, Non Appearance Before the International Tribunal for the law of the Sea op.cit. (Note 108).

${ }^{91}$ ITLOS/PV.19/C.27/2 P.32, lines 44-46. See also dissenting opinions of ITLOS judges j. KATEKA, A. LUCKY, B. BOUGUETAIA et Z. GAO. 


\section{References}

(1997). The Saïga Case (Saint Vincent and the Grenadines vs Guinea), Prompt Release, Judgment of 4 December 1997.

(1998). The Saiga Case, St. Vincent and the Grenadines vs. Guinea). Request for the Prescription of Provisional Measures, Order of 11 March 1998.

(1999). M/V "SAIGA" (No. 2, (Saint Vincent and the Grenadines v. Guinea), ITLOS Reports 1999) (pp. 10, 48, para. 106).

(1999). Saint Vincent and the Grenadines vs Guinea, See Case of the "Saiga" Vessel (No. 2) (Saint Vincent and the Grenadines vs Guinea) (Merits) Judgment, ITLOS, Reports (p. 10).

(1999). The MV "SAIGA" Case (St Vincent and the Grenadines V. Guinea) List of Case: $N^{\circ} 1$, Judgment of 1st July 1999.

(1999). The Southern Bluefin Tuna Case (New Zealand vs Japan; Australia Vs Japan) Provisionary Measures, Order of 27 August 1999, ITLOS, Reports 1999 (p. 280).

(2000). CAMOUCO Case (Panama v. France) Prompt Release, Case N5, ITLOS, Reports 2000 (p. 10, paragraph 71).

(2000). The Camouco Case (Panama vs France), Prompt Release, ITLOS Memorials, Transcripts and Documents (Vol. 5, pp. 228-229).

(2000). The Camuco Case (Panama vs France, Prompt Release, Judgment of 7 February 2000 .

(2000). The MONTE CONFURCO Case (Seychelles v. France) Prompt Release, Case $N^{\circ} 6$, Judgment, ITLOS Reports 2000 (p. 86, Paragraph 90).

(2000). The MONTE CONFURCO Case (Seychelles v. France) Prompt Release, Case $N^{\circ} 6$, Judgment, ITLOS Reports 2000 (p. 208, paragraph 70).

(2000). The Monte Confurco Case (Seychelles vs France), Prompt Release, Judgment of 18 December 2000.

(2001). MOX Plant (Ireland v. United Kingdom), Provisional Measures, Order of 3 December 2001, ITLOS Reports 2001 (pp. 95, 107, para. 60).

(2001). The Chasiri Reefer 2 Case, Prompt Release, Discontinued (Panama vs Yemen), Order of 13 July 2001.

(2001). The Grand Prince Case (Belize vs France), Prompt Release, Judgment of 20 April 2001.

(2002). The Volga Case (Russian Federation vs Australia) Prompt Release, Judgment of 23 December 2002.

(2003). Land Reclamation Case by Singapore in and around the Strait of Johor (Malaysia vs Singapore), Provisionary Measures, and Case $N^{\circ} 12$, Order of 8 October 2003.

(2004). The JUNO TRADER Case (ST Vincent and the Grenadines V. Guinea) Prompt Release, Judgment of 18 December 2004, Case $N^{\circ} 13$.

(2004). The Juno Trader Case, (Saint Vincent and the Grenadines vs Bissau Guinea), Prompt Release, Judgment of 18 December 2004.

(2007). The Hoshinmaru Case (Japan v. Russian Federation), Prompt Release, Case $N^{\circ} 14$, Judgment of 6 August 2007.

(2007). The Hoshinmaru Case (Japan vs Russian Federation), Prompt Release, Judgment of 6 August 2007.

(2007). The Tomimaru Case (Japan vs Russian Federation), Prompt Release, Judgment of 6 August 2007. 
(2012). “ARA Libertad” (Argentina v. Ghana), Provisional Measures, Order of 15 December 2012, ITLOS Reports 2012 (pp. 332, 345, para. 71).

(2013). "Arctic Sunrise” (Kingdom of the Netherlands v. Russian Federation), Provisional Measures, Order of 22 November 2013, ITLOS Reports 2013 (pp. 230, 248, para. 76).

(2013). Arctic Sunrise (Kingdom of the Netherlands v. Russian Federation), Provisional Measures, Order of 22 November 2013, ITLOS Reports 2013 (pp. 230, 242, para. 48).

(2014). The $M / V$ "Virginia G" Case (Panama v. Guinea), Case $N^{\circ} 19$, Judgment of 14 April 2014.

Alexandrov (1995). Non Appearance before the ICJ, 11. Columbia Journal of Transnational Law, 33, 41-72.

Bowett, D. W. (1983). Contemporary Development and Legal Techniques in the Settlement of Disputes. RCADI, 180, 169-235. https://doi.org/10.1163/ej.9789024729623.169-235

Fitzmaurice, S. G. (1980). The Problem of Non Appearing Defendant Government. Bybil, 51, 89-120. https://doi.org/10.1093/bybil/51.1.89

Ndiaye, T. M. (2009). Les procédures contentieuses devant le Tribunal International du Droit de la Mer. In B. Bruylant (Ed.), L'évolution et l'état actuel du droit international de la mer, Mélanges de droit de la mer offerts à Daniel Vignes (pp. 645-690). Bruxelles: Ed. BRUYLANT.

Ndiaye, T. M. (2013). Non Appearance before the International Tribunal for the Law of the Sea. Indian Journal of International Law, 53, 545-564.

Ndiaye, T. M. (2013). Non Appearance before the International Tribunal for the Law of the Sea. Indian Journal of International Law, 53, 545-564.

United Nations Convention on the Law of the Sea (1982). On the Conservation and Management of Fish Stocks Movements Both within and within beyond Exclusive Economic Zones (Straddling Fish Stocks) and Highly Migratory Fish Stocks, Adopted on 4 August 1995. http://www.tidm.org 